\title{
IMPACT OF BRAND IMAGE ON CUSTOMER LOYALTY WITH THE MEDIATING ROLE OF CUSTOMER SATISFACTION AND BRAND AWARENESS
}

\author{
Umair Abbas \\ Bahauddinzakariya University, Multan, Pakistan \\ E-mail: umairmalic0@gmail.com \\ K. M. Anwarul Islam \\ Associate Professor \\ Department of Business Administration \\ The Millennium University, Dhaka, Bangladesh \\ Ph.D. Candidate \\ University of Selangor, Malaysia \\ E-mail: ai419bankingdu@gmail.com \\ Sajid Hussain \\ Bahauddinzakariya University, Multan, Pakistan \\ E-mail: sajid.hussain6441@gmail.com \\ Muhammad Baqir \\ University of Education Lahore, Multan Campus, Pakistan \\ E-mail: baqiralisiddique@gmail.com \\ Noor Muhammad \\ Bahauddinzakariya University, Multan, Pakistan \\ E-mail: noor.tareen730@gmail.com
}

\begin{abstract}
The study indicates the impact of Brand Image on Customer Loyalty with the Mediating Role of Customer satisfaction and Brand Awareness. A questionnaire is filled by the 300 respondents that are selected through non-probability to measure customer satisfaction and their loyalty to their favorite Brand. The respondent filed the questionnaire according to their favorite brand. In the study 22 statements and 5 points, Likert Scaled survey questionnaire was filled by the 300 respondents. The results were made by using different methods. The result is based on the statistics test which displays that the Image of the brand and customer Loyalty is very significant with Customer Satisfaction and Brand Awareness, but Brand Image is insignificant with Brand Awareness. The result is analyzed through SPSS software for statistical analysis. The study was conducted within a short time and within the limited resources due to the pandemic attack of the COVID-19. In the future study, the major topic is recommended due to the current situation in the world due to the pandemic attack of the COVID-19 impact of any pandemic diseases on customer loyalty.
\end{abstract}


Keywords: Brand Image, Customer Loyalty, Customer Satisfaction, Brand Awareness.

JEL Classification Codes: M31, M39.

\section{INTRODUCTION}

A strong Brand Image helps to keep the organization in the mind of potential consumers Customer loyalty is one of the main factors or ownership of the organization that is the major result of brand image and the services level that they are providing to the customers. Therefore, if the company wants to compete with its competitor. They should provide quality products and services to make the customer loyal to their products and services. Awareness and satisfaction of the product increase the overall image of the brand. The satisfaction of the customer is the concept of marketing. The satisfaction of the customer shows how products are delivered to customers. The customer is more satisfied when he gets good quality products at low prices. And when the customer is more satisfied it builds the image of the brand and makes the customer loyal to that product.

Brand awareness is something about the product, quality, and price in the mind of the customer. How much the customer knew about the feature of that brand? However, the customer usually purchases those products that have a decent image in the mind of consumers. The purchasing behavior of the customer is influence through the Awareness of the brand. Brand Awareness is the determinant of business success; many of the researches on the awareness of the brands show that it influences the image of the brand and loyalty of the customer. Brand Image if created meet the expectation from the brand will be leading to satisfaction.

\section{Background Study}

Now a day the competition between the companies is too high. It is very difficult for them to maintain their competitive advantage. From previous few days, the consumers' needs are found that are changing rapidly and which leads to the high pressure on the firms. The purpose of this research is to continue with the existing research on brand image and buyer loyalty. The need for this research is arising as the issue of the brand image buyers loyalty with the mediating role of the satisfaction of the consumers and the awareness about the brand. But the past studies on these variables show that the connection between brand image and the loyalty of the buyers is in the form of high impact. Based on the past studies it is found that the customers highly aware about the product have the greatest loyalty. If the customers are satisfied with the brand they will show loyalty to that product. While the brand image creates more value in the minds of the customers based on some emotions. According to the concepts given above the research, we are going to conduct will concern to explore the influence of brand image on buyers loyalty. Many of the brands are working in Pakistan via this study we will emphasize the measurement for the brands and their influence on the buyers and also the consumers.

\section{Purpose of Study}

The study is designed to check the Impact of a Brand image on the loyalty of the customer with the mediating effect of satisfaction of the customer and brand awareness. Hence the research has the following objectives:

- Check different factors that affect the loyalty of the customer.

- Examine the impact of consumer Satisfaction on the loyalty of customers.

- Analyze the act of Brand Awareness in the satisfaction and loyalty of the customer. 
- Consider the effectiveness of Brand Image in the loyalty of the customer.

\section{Process of Buying Decision}

This process is based on five stages. Most customers go through these stages and some skip these stages. The stages of the buying decision are some of the following.

\section{Stages of Buying Decision}

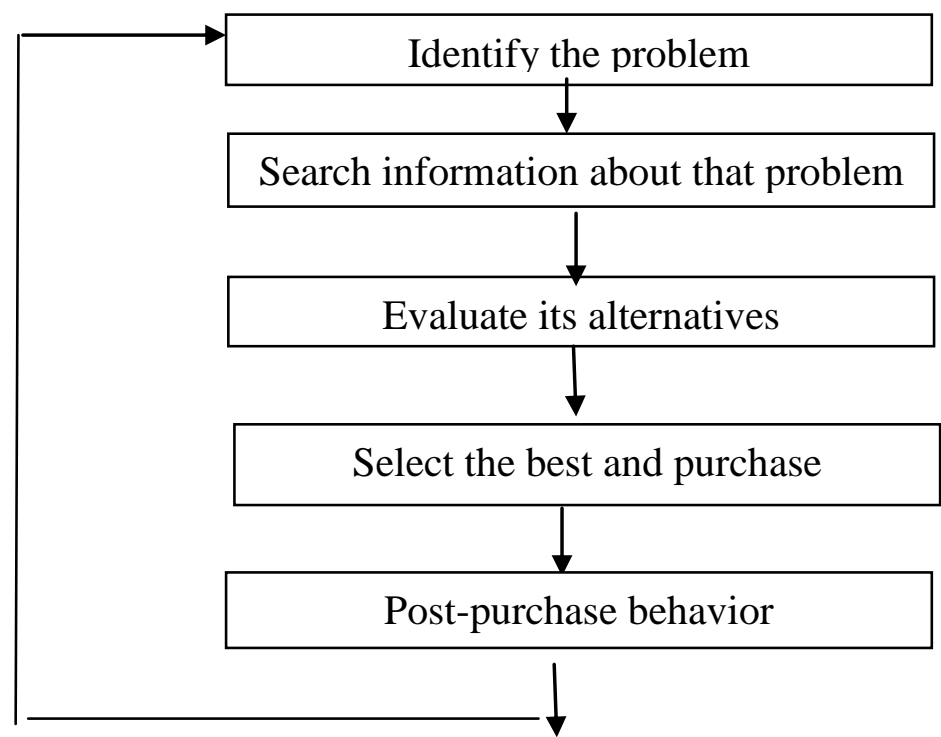

\section{Scope of the Study}

The study is concentrated on peoples who are customers of specific brands. This research provided helpful information about brand preferences to customers.

\section{Limitations of the Study}

The study is focused on different aspects of the loyalty of customers to the Brand Image because of Customer satisfaction and Awareness of the brand. This study is conducted for all brands, not for a specific brand. All cities of Pakistan are not included in the study.

\section{Research Questions}

Some questions about the study are as follows:

- How Image of the Brand affects customer loyalty?

- In what ways consumer satisfaction and brand awareness are mediating the impact of Brand image on the loyalty of the customer?

- What is the relation between the brand and the behavior of customers in the buying decision process?

\section{Brand Image}

\section{LITERATURE REVIEW}

In the marketing field Brand Image is one of the important concepts (Keller, 1998). As the study of (Mao, 2010) in the promotion of a brand, the image of the brands plays a vital role. The image of the Brand is a composite of consumer perception and faith about the brands (Aaker \& Equity, 1991). The image of the Brand is the set of perceptions for a specific brand. This set of 
perceptions plays a vital role in the consumer decision process of purchase when he/she is looking for an alternative brand.(Mishra \& Datta, 2011) Brand image has an optimistic influence on the brand image. On loyalty of the buyer image of the brand has a positive impact. When a customer is satisfied the image of the brand becomes strong. That's way on customer satisfaction Image of the Brand has a positive impact (Johanudin, Nur, \& Shelle, 2016).

Brand Image is not found in the technical characteristics of the original product. But Brand Image is something that brings out by promotions, advertisement. When a customer uses the product and expresses his/her feelings about the product in front of others. That is building a brand image of that product. The image of the brand is something about product features, design, packaging, and the characteristics of that brand or product that make them different and unique from other products.

Brand Image contains how consumers respond to the benefits of its different features which the brand provides to the consumer. Brands can be built through a different process. In the first step make the strategy of the brand and combine it with the business goals. In the second step, we use all our tools to inform the consumer about our brand or the product and services. And the third step to make changes in the brand from time to time with new features and technology which benefit the consumer. The Image of the Brand varies with the perception of the customer. Its example is some consumer-like low price and good quality this low price and high quality make the Image of the Brand. Some consumers like the best and unique quality at any cost. These consumers also think the Brand has a good image and we also advise others to use the products of that brand. Image of the Brand shows the quality of the organization not the colors, name, and logo of that brand. The Image of the Brand becomes stronger when the organization updates its brand faster than rivals. The key role of a Brand is to help the consumer to differentiate the products and services foundations, manufacturing, and differentiate the products and services from rivals/competitors. The image of the brand can become stronger when the brand satisfies the needs and demands of the consumers. If the brand image is positive which will lead to understanding the consumers about the business and the brands? Brand image in terms shows the purpose of your businesses and attracts buyers.

\section{Customer Loyalty}

Is the purchase behavior of the buyer in which he/she buy again and again the same brand product and services in the future regardless of rival efforts? Loyalty can be something about the customer thinking about the product. None of the scholar ye gives the proper definition to the customer loyalty but there are different concepts about it (Jacoby \& Robert, 1978). The organization is focused on customer commitment, which produces a benefit for the consumers that is why they purchase the products of the same brand repeatedly (Sriram, Balachander, \& Kalwani, 2007). The loyalty of the brand is when the consumer buys the products of the same brand again and again. Not all loyal customers look at the price of that brand some of them act as a follower of the company, which contribute to pulling in the customer. The loyalty of the brand can also affect the buying choices of the customer (Wahid \& Ahmed, 2011).

Mostly, there are two viewpoints of brand loyalty. One is behavioral loyalty. Besides the other is attitudinal Loyalty. Behavioral Loyalty is the repurchase of the customer from a similar brand. Attitudinal Loyalty in which the customer repurchases the product without essentially purchase behavior. According to (Chaudhuri \& Holbrook, 2001) stated that there is a direct connection between brand loyalty and the price premium of the brand. The price of the brand is 
the signal of loyalty (Aaker, 1996). The price of the product is paid instead of the other product with the same benefits that may be low or high is known as the price premium.

\section{Customer Satisfaction}

When the goods and services fulfill the need and demands of the customer at an extreme level the customer is said to be satisfied. Services and product attributes and the product itself give pleasure and satisfaction to the customer, the customer is said to be satisfied (Oliver, 1997). In the same way, declared that previous studies on consumer satisfaction highlight mostly on influence of the hopes, performance, and affect in addition to equity on satisfaction. Satisfaction on the product is like service or product excellence, service or product hospitality, practice design, perceived value, and customer relationship advantages. Customer Satisfaction is something that how the firm product performance is according to the requirement of the customer. In the same way, some other researchers said that the loyalty of the customer and customer Satisfaction is separate from each other. Satisfaction is something that people say about the product. And Loyalty is what people do. The customer becomes loyal when he is satisfied with the product and services of that brand. From the Loyal customer, the organization makes more profit because the loyal customer purchases the same Brand products again and again and commends others to purchase the same products and services. Loyal Customers cannot switch to other brand products and sincere with their brand's product. In different market situations and marketing efforts, customers will not switch to rival and other brands. Loyal customers are an asset for the organization and valuable in making profit and sustainability. According to (Bowen \& Shoemaker, 2003) if the customers are satisfied with a brand they will show a positive image and have positive words about the brand. The consumers' are not satisfied the major consequences are that firm is not able to deliver according to the expectations of the consumers' (Roig, Garcia, Tena, \& Monzonis, 2006).

\section{Brand Awareness}

It is something that customer ever watches and heard about the brand we can say that he/she is aware of the brand and know the brand effectively (Brewer \& Zhao, 2010). Also, the name of the brand is the most significant. In decision-making Brand, awareness helps the customer. By knowing well about the Brand and have awareness about the Brand the customer made buying decisions easily. Customers gain brand awareness through the internet, newspaper, radio, and other media of information. When the customer is aware of the merit and demerits of the brand this awareness reduces the threat in product selection. Brand awareness links the customer with the brand they aspire to possess (Pouromid \& Iranzadeh, 2012). The best awareness about the brand comes when the consumer uses the products of the brand. The consumer is aware of the brand when he saw the brand and sees a different advertisement on the media. Through the media, he becomes aware of the feature and working of the brand products.

When the consumer is aware of the brand's features and thinks this brand can fulfill its needs then he decides to purchase that brand. (Tong \& Hawley, 2009) Brand Awareness is the characteristic of the consumer when he is going to purchase the product of the brand.

\section{Brand Image and Customer Satisfaction}

The positive image of the brands improves the satisfaction of the customer. When a customer is aware of the brand and uses that brand if a customer is satisfied with the brand it builds the image of the brand. A positive brand image improves customer satisfaction. Customer 
satisfaction helps to construct the image of the brand. (Hess \& Story, 2006) The image of the brand is important for an organization that moves towards Customer satisfaction. Through Image of the Brand and customer satisfaction organization improve their effectiveness. When applying this concept to the store. This concept shows that the effects of store image are linked with store Satisfaction. The good relationship between the corporation and the customer shows the connection between brand image and consumer satisfaction. The researcher says there is no important relationship between loyalty and satisfaction (Zins, 2001). However, the image of the organization is linked to customer satisfaction (Kandampully \& Suhartanto, 2000). Loyalty improves the image of the brand. And the image of the brand is a good consumer is more satisfied to purchase that brand. When an organization provide quality at a low price and fulfill the needs and demands of consumer the consumer is more satisfied which help to improve the image of the brand. By improving the image of the brand, the organization enjoys more profit and goodwill.

$\mathbf{H}_{1}$ : Image of the brand and customer satisfaction is directly proportional to each other. As the customer is satisfied, more the image of your brand will be made.

\section{Customer Satisfaction and Customer Loyalty}

Different studies show that when the customer is satisfied with the brands, he becomes loyal to that brand (Ismail, Ibrahim, \& Mohd, 2006). It shows a direct connection between the satisfaction of the buyer and customer loyalty. If the buyer is gratified with the brand products and services. Customers do praise that brand in front of others. Due to high satisfaction from the brand, a customer has less chance to move toward another brand (Bennet \& Rundle-Thiele, 2004). Many studies confirmed that the satisfaction of the customer has a positive effect on customer Loyalty. It includes different intents of the customer. Intent to purchase again and again the same brand. Intent to suggest the same brand to others which he uses (Kandampully \& Suhartanto, 2000). Intent to visit the same store again and again (Bloemer, Deruyter, \& Peeters, 1998). Studies show that the satisfaction of the customer is the key factor of buyer loyalty (Szware, 2005). Some studies are not satisfying on this point (Gommans, Krishman, \& Sheffold, 2001) some Customer who is loyal but not satisfied from the brand and some are the customer who is satisfied but not loyal with that brand. When the brand is satisfying the need and demands of the consumer he becomes more satisfied with the brand. And when the consumer is satisfied he becomes loyal which is beneficial for the organization. For making customers loyal to the brand organization needs to develop a strong brand to know their target audience and make strategies according to their target audience. Make their products according to the needs of the consumer and low prices than the rival. Provide good quality at a low price also makes the customer loyal to that brand.

$\mathbf{H}_{2}$ : Customer satisfaction also Customer Loyalty are directly proportional to each other. As the buyer is satisfied, the more he/she became loyal.

\section{Brand Image and Brand Awareness}

Many hypothetical and the applied indications from the recent learning show the direct connection between the image of the brand and brand awareness. According to (Aaker \& Equity, 1991) that the brand image and awareness about the brand have a solid connection among each other as awareness about the brand is an important matter that supports a brand to persist in the 
awareness of the consumer. Whereas, according to (Aaker, 1996) that from the study is found that brand image and brand awareness have to get in the justification. By the study to (Tong \& Hawley, 2009), brand awareness is the basic part of a consumer brand. Awareness of the brand is tended to build the image of the brand in the approach to the consumer awareness of the brand has some impact on the observation and behavior of the consumer. Many researchers show that the awareness of the brand can build the image of the brand. When a customer is aware of the features and characteristics of the brand he/she feels no reluctance to purchase that brand. Because he is known about the brand and purchases it because he is satisfied it will help to improve the image of the brand. Brand awareness is necessary to maintain the brand image in buyer's perception of the brand is already known in the market and the buyers know about the brand it will create the easy association in the minds of customers. If the awareness about the brand is high the buyers will adopt the brand easily with less time.

$\mathbf{H}_{3}$ : Awareness of the brand has some connection with the image of the brand.

\section{Brand Awareness and Customer loyalty}

From the satisfaction of the consumer, we can predict the future purchase of the consumer. The consumers that are more satisfied with the product will purchase more next time according to the (Zeithaml, Berry, \& Parasuraman, 1996) are recommended that the customers try to have the satisfaction about the services and the goods and also give the less response towards the competitors' products that they are offering in the market. Mostly, loyalty has been found as an important part of brand awareness according to (Zeithaml, Berry, \& Parasuraman, 1996). At the same time, awareness and loyalty about the product are most of the time linked by many of the researchers' study. Many of the others have considered it as the relation between the competitors' products whereas some of the others even did not get any of the direction and are unidirectional. Brand awareness tends to the customers that are product satisfied or is not complete without the other variables that are mediating. They mostly tend to be used as the most important purpose of the repurchase and to devote the name of the brand for their connection (Zeithaml, Berry, \& Parasuraman, 1996).

$\mathbf{H}_{4}$ : Brand awareness has a significant positive connection with the loyalty of the customer.

\section{Brand Image, Brand Awareness, and Customer Loyalty}

How the customer recognizes the image of the brand in their minds and has great significance besides the real one. Definition of brand image is how buyer takes the specific brand, and the uniqueness of the brand is the criteria via which most of the companies introduce their new brands in the market and what they are hoping and doing for the awareness of the product to the customers to purchase their new product. It is a possibility that the customers can have a different brand image and they are firm in offering the difference (Bian \& Moutinho, 2011). During the previous few years due to scientific improvement, the buyers have become more aware of products and they just purchase that product about which they know a lot and have clear information about the features and are also according to their requirements. Each of the companies has the wish to compete with their competitors and for this purpose, they can do any of the actions and which possible if the customers purchase their product instead of their competitors. According to (Macdonald \& Sharp, 2000) that although the customer wants to purchase his favorite product still you have the chance to convince him to change the buying 
behavior of the customer. As the consumer is introduced by any of the products mostly their focus is on the title of the brand that shows the awareness of the brand. The consumer's decision to purchase any of the products cannot be changed if the customer about the brand has high awareness. The discussion shows that those products have a high level of shares and better value in the market that have a higher level of awareness about the brand. Rather than this, when the customer purchases any of the products in the market he considered or focus on brand awareness and its value in the market at that time. According to Aaker (Aaker \& Equity, 1991) if the customer focuses on the value of the product at the time of purchase it will help him to decide on the product and the product has the best features and becomes a good brand in the minds of the customers. Now a day, companies have to focus on the loyalty of the customers. The cost now a day is five-time higher than before. Awareness about the brand helps the consumer to purchase the product. If the consumer is satisfied with the product of that brand he becomes loyal that improves the overall image of the brand and vice versa.

H5: There is always a direct connection between brand image, brand awareness and loyalty of the customers and the brand image is affecting the customer loyalty and brand awareness is playing the role of mediator.

\section{Brand Image, Customer Satisfaction, and Customer Loyalty}

The image of the brand always remains one of the important assets for the satisfaction of the customers and their loyalty to the product. Customer loyalty and brand image have an impact on each other. Got that the image of the brand harms the loyalty of the customers according to the satisfaction of the customers. The satisfaction of the customer is one of the very major drivers of customer loyalty and in any of the business growth. As recent studies show according to (Davies, Chun, DaSilva, \& Roper, 2003) that there is a direct connection between the customer's satisfaction and brand image and the favor of the brand image creates loyalty about the product. Many of the researchers showed that there is a good result in between the direct connection of the satisfaction of the customer and the again purchase which is loyalty-based. Many of the studies shown that the flaw is shown by the satisfaction of the customers (Dimitriades, 2006) When the consumers say the product has satisfied them, they will still purchase the product from somewhere else elsewhere (Jones, 1996). The learning has shown that there is a positive connection between consumer satisfaction, buyer loyalty, and repurchase (Bloemer \& Odekerken- Schroder, 2002). Many of learning's stated that the customers which are satisfied can decrease their purchases (Dimitriades, 2006). As, most of the consumers' reply is that they are satisfied with the products but at that time they are purchasing some other brand (Jones, 1996).

$\mathbf{H}_{6}$ : There is a significant direct connection between brand image, the satisfaction of the customers, and the loyalty of the customers. Image of the brand is affecting consumer loyalty and consumer satisfaction is playing the role of mediator. 


\section{THEORETICAL FRAMEWORK}

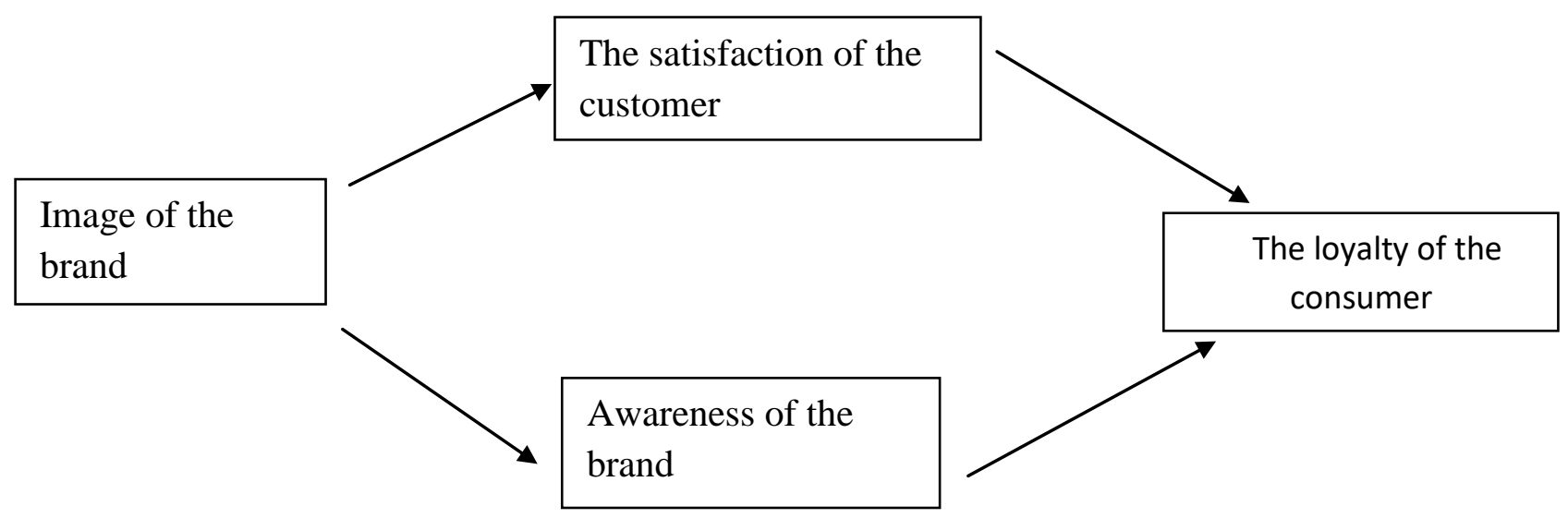

Figure 1. Theoretical Framework

\section{METHODOLOGY}

The major reason for the study is to understand the customer loyalty scope from a customer point of view. This learning involved the sampling method and the cross-sectional strategy and in this research, the data was gathered from 300 responders that were consuming brands that were different. The questionnaire was made based on the objectives of the research. The data collected via questionnaire is taken as the first time data which is called primary data. The questionnaire includes the 22 statements from these 4 statements were about the demographic or which includes the personal information and the others include the perception about the variables that are about the study. The questionnaire that was adapted was utilized to gather the data from buyers of the different brands. The tool typically used in the research was the five options Likert Scale. The main reason behind this scale was that the customers have many of the choices according to their feelings about the brand. The questionnaire had multiple options in the question. The questionnaire that was used in the collection of the data has two sections. The first section has the personal information of the responder that was the age factor, gender factor, education, and income factor. In the second section, the data about the dependent variable was collected and with this variable, the data was collected about the independent variable and both mediating variables. The points that strongly disagreed, disagree, neutral, agree, and strongly agree according to the arrangement of numbers. In other segments, the consumers of the different brands were asked to fill the questions according to their choice according to the scale. The responders were mostly the students of the Bahaudin Zakariya University Multan and others were citizens of Multan city most respondents were under the age of 19 to 23 and were male.

\section{RESULT AND DISCUSSION}

Image of the brand and consumer loyalty are taken as the determinant's consumer choosing related to any of the products and it considers the competitor situation for the definite firm to defeat in the market. The current learning was under reserved with the situation that what the specific issues help towards the loyalty of the consumers and their satisfaction.

All of the brands were taken as case studies as domestic consumers consider for purchasing the specific brand have to discuss in the sense of brand image and buyer loyalty. In this section, the outcome is given and discussed. Brand image and loyalty of the buyer are 
decided as the possession of the company and it can appeal to the consumers towards the brand. In this study, the brand image and loyalty of the buyer and their relation with the satisfaction of the consumer and awareness of the brand are decided through the research.

\section{Demographic Characteristics}

To measure the dimensions of all of the customers the data gathered from 300 respondents that were the users of the different brands. From all of these respondents there are $166(55 \%)$ male respondents and $134(45 \%)$ are female respondents. The majority of the responders are under the age of 19-23 years.

\section{Reliability Analysis}

The data which was gathered was calculated and the result shows that the value of Cronbach's alpha of brand image is .620 , the loyalty of the brand value is .530 , customer satisfaction measure is .622, and awareness of the brand is .618. Therefore, the reliability of the data that is given in the learning is in the normal range.

Table 1.Reliability of Statistics

\begin{tabular}{|l|l|}
\hline Cronbach. Alpha & Numbers of the items \\
\hline .666 & 4.00 \\
\hline
\end{tabular}

Table 2. The item Total Statistic

\begin{tabular}{|l|l|l|l|l|}
\hline & $\begin{array}{l}\text { Scale means } \\
\text { if the Item } \\
\text { Removed }\end{array}$ & $\begin{array}{l}\text { Scale } \\
\text { variance if } \\
\text { the Item } \\
\text { Removed }\end{array}$ & $\begin{array}{l}\text { Modified } \\
\text { Item Total } \\
\text { Correlation }\end{array}$ & $\begin{array}{l}\text { Cronbach } \\
\text { alpha if the } \\
\text { Item } \\
\text { Removed }\end{array}$ \\
\hline Brand Image & 6.5469 & 1.761 & .418 & .620 \\
\hline Brand Loyalty & 6.2409 & 1.470 & .545 & .530 \\
\hline $\begin{array}{l}\text { Customer } \\
\text { Satisfaction }\end{array}$ & 6.4251 & 1.662 & .412 & .622 \\
\hline Brand Awareness & 6.2698 & 1.481 & .428 & .618 \\
\hline
\end{tabular}

\section{Exploratory Analysis}

In the table below all of the findings show that the distribution of the variables according to the skewness is normal values that fluctuated between -1.0 to +1.0 . Standard deviation also means are given in the table below:

Table 3. Descriptive Statistics

\begin{tabular}{|l|l|l|l|l|l|l|l|l|l|l|}
\hline & Number & Maximum & \multicolumn{2}{|l|}{ Mean } & $\begin{array}{l}\text { Standard } \\
\text { Deviation }\end{array}$ & Variance & \multicolumn{2}{l|}{ Skewness } & \multicolumn{2}{l|}{ Kurtosis } \\
\cline { 2 - 10 } & Statistic & Statistic & Statistic & $\begin{array}{l}\text { Std. } \\
\text { Error }\end{array}$ & Statistic & Statistic & $\begin{array}{l}\text { Stat } \\
\text { istic }\end{array}$ & $\begin{array}{l}\text { Std. } \\
\text { Erro } \\
\mathrm{r}\end{array}$ & Statistic & $\begin{array}{l}\text { Std. } \\
\text { Error }\end{array}$ \\
\hline Brand & 300.00 & 3.40 & 1.9473 & .02840 & .49183 & .242 & .74 & .141 & .115 & .281 \\
\hline
\end{tabular}




\begin{tabular}{|c|c|c|c|c|c|c|c|c|c|c|}
\hline Image & & & & & & & 6 & & & \\
\hline $\begin{array}{l}\text { Brand. } \\
\text { Loyalty }\end{array}$ & 300.00 & 4.33 & 2.2533 & .03294 & .57046 & .325 & $\begin{array}{l}.77 \\
2\end{array}$ & .141 & .540 & .281 \\
\hline $\begin{array}{l}\text { Custom } \\
\text { er. } \\
\text { Satisfac } \\
\text { tion }\end{array}$ & 300.00 & 4.25 & 2.0692 & .03179 & .55055 & .303 & $\begin{array}{l}1.0 \\
03\end{array}$ & .141 & 1.628 & .281 \\
\hline $\begin{array}{l}\text { Brand. } \\
\text { Awaren } \\
\text { ess }\end{array}$ & 300.00 & 4.33 & 2.2244 & .03674 & .63643 & .405 & $\begin{array}{l}.59 \\
0\end{array}$ & .141 & .168 & .281 \\
\hline $\begin{array}{l}\text { Valid } \\
\text {.N } \\
\text { (leastwi } \\
\text { se) }\end{array}$ & 300.00 & & & & & & & & & \\
\hline
\end{tabular}

Table 4. Descriptive Statistic

\begin{tabular}{|c|c|c|c|c|}
\hline & Mean & \multicolumn{2}{|c|}{ Standard Deviation } & Number \\
\hline Brand Image & 1.9473 & .49183 & 300 & \\
\hline Brand Loyalty & 2.2533 & .57046 & 300 & \\
\hline $\begin{array}{l}\text { Customer } \\
\text { Satisfaction }\end{array}$ & 2.0692 & .55055 & 300 & \\
\hline Brand Awareness & 2.2244 & .63643 & 300 & \\
\hline
\end{tabular}

\section{Correlation Analysis}

In this analysis, the test which is used is the Pearson correlation test shows the association between the variables. The table which is given below shows the correlation is + with brand loyalty. Image of the brand is $(\mathrm{r}=0.7590)$ loyalty of the brand $(\mathrm{r}=.3410)$, customer satisfaction $(\mathrm{r}=.213)$, brand awareness $(\mathrm{r}=.000)$. The correlation of the coefficients between the variables that stay independent is not more than the value of 0.9 , which removes the multicollinearity issue.

Table 5. Correlation

\begin{tabular}{|l|l|l|l|l|l|}
\hline \multicolumn{2}{|c|}{} & $\begin{array}{l}\text { Brand } \\
\text { Image }\end{array}$ & $\begin{array}{l}\text { Brand } \\
\text { Loyalty }\end{array}$ & $\begin{array}{l}\text { Customer } \\
\text { Satisfaction }\end{array}$ & $\begin{array}{l}\text { Brand } \\
\text { Awareness }\end{array}$ \\
\hline Brand Image & $\begin{array}{l}\text { Pearson. } \\
\text { Correlation. }\end{array}$ & 1 & $.406^{* * *}$ & $.341^{* * *}$ & $.213^{* * *}$ \\
\cline { 2 - 7 } & Sig.2 - tailed & & 0.0000 & 0.0000 & 0.0000 \\
\cline { 2 - 7 } & Number & 300.00 & 300.00 & 300.00 & 300.00 \\
\hline \multirow{3}{*}{ Brand Loyalty } & $\begin{array}{l}\text { Pearson. } \\
\text { Correlation }\end{array}$ & $.406^{* * *}$ & 1 & $.315^{* * *}$ & $.452^{* * *}$ \\
\cline { 2 - 7 } & Sig..2- tailed & 0.0000 & & 0.0000 & 0.0000 \\
\cline { 2 - 7 } & Number & 300.00 & 300.00 & 300.00 & 300.00 \\
\hline \multirow{3}{*}{ Customers } & $\begin{array}{l}\text { Pearson. } \\
\text { Correlation }\end{array}$ & $.341^{* * *}$ & $.315^{* * *}$ & 1 & $.288^{* * *}$ \\
\hline
\end{tabular}




\begin{tabular}{|l|l|l|l|l|l|}
\hline satisfaction & Sig..2 - tailed & 0.0000 & 0.0000 & & 0.0000 \\
\cline { 2 - 6 } & Number & 300.00 & 300.00 & 300.00 & 300.00 \\
\hline \multirow{8}{*}{ Brand Awareness } & $\begin{array}{l}\text { Pearson. } \\
\text { Correlation }\end{array}$ & $.213^{* *}$ & $.452^{* *}$ & $.288^{* *}$ & 1 \\
\cline { 2 - 6 } & Sig..2 - tailed & 0.0000 & 0.0000 & 0.0000 & \\
\cline { 2 - 3 } & Number & 300.00 & 300.00 & 300.00 & 300.00 \\
\hline
\end{tabular}

\section{CONCLUSION}

This research studied the connection between brand image and loyalty of the buyer with the mediating role of the satisfaction of the customer and awareness of the brand. All of the brands were taken as the object for the research study. In light of the research is concluded that brand image has an important impact on customer loyalty. Although, brand awareness and consumer satisfaction influence the brand image and customer loyalty according to the results. As a large part of the responders were youngsters and were qualified.

This research also emphasized that responders were mostly influenced by the favorites related to their choices of the brand and quality and which built a strong + correlation with brand image and customer loyalty of product.

In the end, it is the satisfaction of the consumer and creates interest of the consumer to the use of the product and specific brand. Brand awareness also plays a significant part in the relation of brand image with customer loyalty. If the product will be unique the customers will prefer that.

\section{LIMITATIONS AND THE FUTURE STUDY}

The study was conducted within a short time and within the limited resources due to the pandemic attack of the COVID-19. The respondents were only from the single culture of the Multan. The questionnaire includes statements about all brands not about a specific brand and the questionnaire that is used in the research were close-ended. Some of the difficulties found during the research that there was a language difference responders mostly not able to understand English and most of them were Urdu speaking. In the future study, the major topic is recommended due to the current situation in the world due to the pandemic attack of the COVID19 impact of any pandemic diseases on customer loyalty.

\section{RECOMMENDATIONS}

The companies should provide attention to the customers they have to give them the products as affordable and have to provide rapid services. The companies can attract the customers when they are launching the new product by giving them gifts through this they can promote their products. The high brand image can lead to customer loyalty and satisfaction the companies should provide the packages of the goods at a cheap price.

\section{REFERENCES}

Aaker, D. A. (1996). Measuring brand equity across products and markets. California management review, 38(3), 102-120.

Aaker, D. A., \& Equity, M. B. (1991). Capitalizing on the value of a brand name. New York. 
Bennet, R., \& Rundle-Thiele, S. (2004). Customer satisfaction should not be the only goal. journal of service Marketing, 18(7), 514-523.

Bian, X., \& Moutinho, L. (2011). The role of brand image, product involvement, and knowledge in explaining consumer purchase behavior of counterfeits: Direct and indirect effects. European Journal of Marketing, 45(1/2), 191-216.

Bloemer, J. M., \& Odekerken- Schroder, G. (2002). Store satisfaction and store loyalty are explained by customer and store-related factors. Journal of consumer satisfaction, dissatisfaction, and complaining Behavior, 15, 68-79.

Bloemer, J., Deruyter, K., \& Peeters, P. (1998). Investigating drivers and satisfaction. The international journal of Banking Marketing, 16(7), 276-286.

Bowen, J. T., \& Shoemaker, S. (2003). Loyalty: A strategic commitment. Cornell Hotel \& Restaurant Administration Quarterly, 44(5/6), 31-46.

Brewer, A., \& Zhao, J. (2010). The impact of a pathway college on reputation and brand awareness for its affiliated university in Sydney. international journal of Educational Management, 24(1), 34-37.

Chaudhuri, A., \& Holbrook, M. B. (2001). The chain of effects from brand trust and brand effect to brand performance: The role of brand loyalty. journal of Marketing, 65 (April), 81-93.

Davies, G., Chun, R., DaSilva, R., \& Roper, S. (2003). corporate reputation and competitiveness. London: Routledge.

Dimitriades, Z. S. (2006). Customer satisfaction, loyalty, and commitment in service organizations: Some evidence from Greece. Management Research News, 29(12), 787 799.

Gommans, M., Krishman, K., \& Sheffold, K. (2001). From Brand loyalty to e-loyalty: A conceptual framework. journal of Economics and social research, 3(1), 43-58.

Hess, J., \& Story, J. (2006). Trust-based commitment: multidimensional consumer-brand relationships. journal of Consumer Marketing, 21(5), 321-345.

Ismail, I. H., Ibrahim, B., \& Mohd, I. S. (2006). Service quality, client satisfaction and loyalty towards audit firms: perceptions of Malaysian public listed companies. managerial Auditing Journal, 22(7), 738-756.

Jacoby, J., \& Robert, C. (1978). Brand loyalty measurement and management. New York: John Wiley \& Sons.

Johanudin, L., Nur, S., \& Shelle, M. R. (2016). A study of the brand image towards customer satisfaction in the Malaysian Hotel industry. social and behavioural science, science direct, IRSSM-6 (2015). 
Jones, T. (1996). Why satisfied customer defect. journal of Management in Engineering, 12(6).

Kandampully, J., \& Suhartanto, D. (2000). customer loyalty in the hotel industry: the role of customer satisfaction and image. international j. contemporary Hospitality Management, 12(6), 346-351.

Keller, K. L. (1998). Strategic Brand Management: Building, Measuring, and Managing Brand Equity. New jersey: prentice-Hall.

Macdonald, E., \& Sharp, B. M. (2000). Brand awareness effect on consumer decision making for a common, repeat purchase product: A replication. journal of business research, 48(1), 515.

Mao, J. (2010). Customer brand loyalty. International journal of business and management, 5(7), 213-217.

Mishra, P., \& Datta, B. (2011). Brand name: The impact factor. Research journal of business management, 5(3), 109-116.

Oliver, R. (1997). Satisfaction: A behavioral perspective on the consumer (ed). New York, NY: McGraw-Hill.

Pouromid, B., \& Iranzadeh, S. (2012). The Evaluation of the factors Effects on the Brand Equity of pars Khazar Household Appliances Based on the vision of female consumer. MiddleEast Journal of Scientific Research, 12(8), 1050-1055.

Roig, J. G., Garcia, J. S., Tena, M. A., \& Monzonis, J. L. (2006). customer perceived value in banking services. international journal of Banking marketing, 24(5), 266-283.

Sriram, S., Balachander, S., \& Kalwani, M. U. (2007). Monitoring the dynamics of brand equity using store level data. journal of marketing, 71, 61-78.

Szware, P. (2005). Researching customer satisfaction and loyalty: How to find out what people think. London: Kogan page limited.

Tong, X., \& Hawley, J. M. (2009). Measuring customer based brand equity: empirical evidence from the sportswear market in China. Journal of Product \& Brand Management, 18(4), 262-271.

Wahid, N. A., \& Ahmed, M. (2011). The effect of attitude toward advertisement on Yemeni female consumers attitude toward brand and purchase intention. Global Business and Management Research, 3(1), 21.

Zeithaml, V., Berry, L., \& Parasuraman, A. (1996). The behavioral consequences of service quality. journal of marketing, 60(2), 31-46. 
Zins, A. (2001). Relative attitude and commitment in customer loyalty models: Some experiences in the commercial airline industry. international journal of service industry Management, 12(3), 269-294.

\section{Copyrights}

Copyright for this article is retained by the author(s), with first publication rights granted to the journal. This is an open-access article distributed under the terms and conditions of the Creative Commons Attribution license (http://creativecommons.org/licenses/by/4.0/). 